J. Clin. Chem. Clin. Biochem.

Vol. 17, 1979, pp. 781-787

\title{
Improvement of the Calcitonin Radioimmunoassay ${ }^{1}$ )
}

\author{
By W. G. Wood, O. A. Müller, G. Stalla and P. C. Scriba \\ Laboratories for Clinical Chemistry and Endocrinology, Medizinische Klinik Innenstadt \\ (Director: Professor Dr. E. Buchborn) der Universität München
}

(Received January 29/May 29, 1979)

Summary: A rapid and specific assay for human serum calcitonin is described.

The total assay-time is under $24 \mathrm{~h}$ and uses double-antibody in combination with polyethylene gly col to separate bound and free hormone.

The antibody has been checked for its affinity to human serum calcitonin by using a Scatchard plot. Geometric dilution of sera from patients with medullary thyroid carcinoma showed a linear relationship with measured values approximating those expected.

The use of Florisil to extract human serum calcitonin from sera to make "human calcitonin-free"-serum for standards has been investigated. A series of 52 normal volunteers and 99 patients with medullary thyroid carcinoma or other possible calcitonin-metabolism disorders have been examined. Only the medullary thyroid carcinoma-patients showed significantly elevated results. In the other groups two patients with phaeochromocytoma and one patient from 29 with bronchial carcinoma had elevated serum calcitonin levels.

\section{Verbesserung der radioimmunologischen Calcitonin-Bestimmung}

Zusammenfassung: Es wird ein verbesserter Radioimmunoassay für menschliches Calcitonin vorgestellt. Die Gesamtdauer der Bestimmung liegt unter 24 Stunden. Zur Trennung von gebundenem und freiem Hormon wird eine Doppelantikörper-Methode unter Zusatz von Polyethylenglykol eingesetzt. Das Antiserum wurde bezüglich seiner Affinität zu menschlichem Calcitonin unter Einsatz des Scatchard-Plots untersucht. Serumverdünnungsreihen von Patienten mit erhöhten Calcitonin-Konzentrationen bei medullärem Schilddrüsenkarzinom lagen stets auf der Standardkurve. Es werden Versuche zur Extraktion von menschlichem Calcitonin aus Patientenseren zur Herstellung eines "Calcitonin-freien" Serums beschrieben.

Wir untersuchten 52 stoffwechselgesunde Normalpersonen und 99 Patienten mit medullärem Schilddrüsenkarzinom, Phaeochromocytom, Bronchialkarzinom oder anderen Calcium-Stoffwechselstörungen. Nur in der Gruppe der Patienten mit medullärem Schilddrüsenkarzinom fanden sich signifikant erhöhte Calcitonin-Konzentrationen. In den anderen Gruppen fanden sich lediglich bei zwei Patienten mit einem Phaeochromocytom sowie bei einem Patienten von einer Gruppe von 29 Patienten mit Bronchialkarzinom erhöhte Serum-Calcitonin-Konzentrationen.

\section{Introduction}

Since the introduction of a radioimmunoassay (RIA) for human calcitonin $(1,2)$ the following problems have not been fully resolved:

(1) Long assay time - usually in the order of several days $(1,2)$.

1) Supported in part by the Deutsche Forschungsgemeinschaft (Sonderforschungsbereich 51 ) and by the Bundesministerium fir Forschung und Technologie (BMFT).
(2) Sensitivity - thus requiring an extraction step for measurement in normal persons (3).

(3) Separation - the use of non-specific separation of bound and free hormone (4).

This study has taken these points and developed an assay which gives results inside $30 \mathrm{~h}$, needs no extraction and uses a second antibody-polymer separation step (5). To prove the reliability of the assay, parallel-dilution tests, as well as a clinical study have been conducted over a 12 month-period, including sera from patients with medullary thyroid carcinoma, bronchial carcinoma and calcium metabolism disturbances. 


\section{Materials and Methods}

The antiserum, coded 030377 , donated by Professor $R$. Ziegler, Ulm, was raised in a goat against synthetic 1-32 human calcitonin (CIBA-Geigy) (6).

The standard for labelling and in the assay was also the 1-32 humun calcitonin from CIBA.

Standard curves were set up in "human calcitonin-free" serum (tested against a buffer-standard curve) except where otherwise stated. Precipitating antiserum (2. Ab) (Donkey-antisheep-goat) was obtained from Wellcome (D-6100 Darmstadt).

125I-human calcitonin was produced by a modified Hunter \& Greenwood method as published elsewhere for parathyrin (7) and had a shelf-life of longer than 3 months. Purification of label was effected by means of a $9 \times 1 \mathrm{~cm}$ Sephadex G-10 column and the labelled human calcitonin stored in buffer 2 (see table 1).

The assay was carried out as in table 1 .

\section{Results}

Preliminary Studies

\section{Antibody Dilution Curve}

An antibody concentration of 1:10 000 (initial dilution) was chosen to give a $B_{0} / T$ ratio of around 0.2 after an incubation time of $6 \mathrm{~h}$ at $4{ }^{\circ} \mathrm{C}$.

\section{Kinetic Studies of Tracer Binding}

Figure 1 shows the kinetics of the zero and $2.5 \mu \mathrm{g} \cdot$ liter $^{-1}$ standards over a $7 \mathrm{~h}$ period after a $15 \mathrm{~h}$ preincubation at $4{ }^{\circ} \mathrm{C}$. The second incubation was set at $4.5 \mathrm{~h}$ from these results. The pre-incubation was set at $15 \mathrm{~h}$ - i.e. overnight - as a part of the rationalisation programme. A preincubation step was included to increase sensitivity as shown for other peptide hormones (8).

Tab. 1. Assay details showing incubation, separation and counting steps.

Pre-Incubation $\quad 18 \mathrm{~h} \quad 4^{\circ} \mathrm{C}$
$\begin{gathered}100 \mu 1 \\ 100 \mu l \text { anti human calcitonin } \\ \text { in }{ }^{+} \text {buffer } 2\end{gathered}$

Main Incubation $\quad 4.5 \mathrm{~h} \quad 4^{\circ} \mathrm{C}$

$100 \mu 1^{125}$ I-human calcitonin in buffer 2 (ca. $260 \mathrm{~Bq}$ )

Separation

Reagent-addition $+10 \mathrm{~min}$ at room temperature

$50 \mu \mathrm{l}$ Sheep $\gamma$-globulin $(10 \mu \mathrm{g})$

$50 \mu$ l Donkey-anti-sheep/goat precipitating serum

$500 \mu$ l Polyethylene gly col $\left(M_{\mathrm{r}} 6000 ; 60 \mathrm{~g} \cdot\right.$ liter $\left.^{-1}\right)$

\begin{tabular}{ll}
$\begin{array}{l}\text { Centrifugation } \\
\text { Counting }\end{array}$ & $15 \mathrm{~min} \quad 3000 \mathrm{~g} \quad 4^{\circ} \mathrm{C}$ \\
& $\begin{array}{l}\text { Precipitate after aspiration of super- } \\
\text { natant. } \\
2 \mathrm{~min} / \text { tube }-10,000 \text { counts in zero } \\
\text { standard }\end{array}$ \\
\hline+ standards in "human calcitonin-free" serum, range $0.08-$ \\
$10 \mu \mathrm{g} \cdot$ liter \\
++ buffer $2=0.05 \mathrm{~mol} / 1$ barbital buffer $\mathrm{pH} 7.4$ containing $10 \mathrm{~g}$ \\
human serum albumin and $500,000 \mathrm{KIU}$ aprotinin (Trasylol) \\
per liter.
\end{tabular}

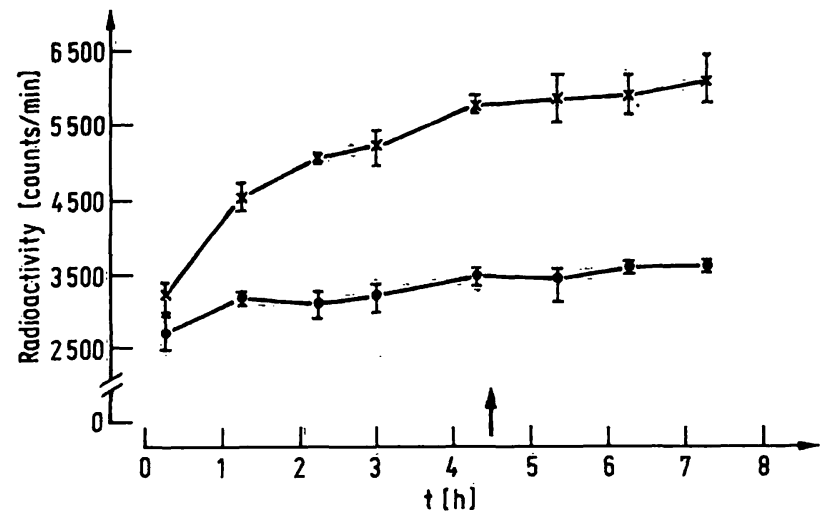

Fig. 1. Binding kinetics of the zero $(\mathrm{x}-\mathrm{x})$ and $2.5 \mu \mathrm{g} \cdot \operatorname{liter}^{-1}$ $(\bullet-6)$ standards. $18 \mathrm{~h}$ pre-incubation $4{ }^{\circ} \mathrm{C}$. Arrow denotes chosen tracer incubation time.

\section{Affinity Studies}

A Scatchard-plot carried out unter the assay conditions gave a population of antibodies with an affinity constant of $0.31 \times 10^{11}$ liter $\cdot \mathrm{mol}^{-1}$ and shows why the assay can be carried out in such a short time. A second population of low affinity-high capacity antibodies with an affinity constant of $0.28 \times 10^{9} \mathrm{liter} \cdot \mathrm{mol}^{-1}$ was also seen.

\section{Tracer - Preparation and Purification}

Figure 2 shows the purification of the label over Ultrogel AcA 54 after desalting of the reaction-mixture on Sepha-

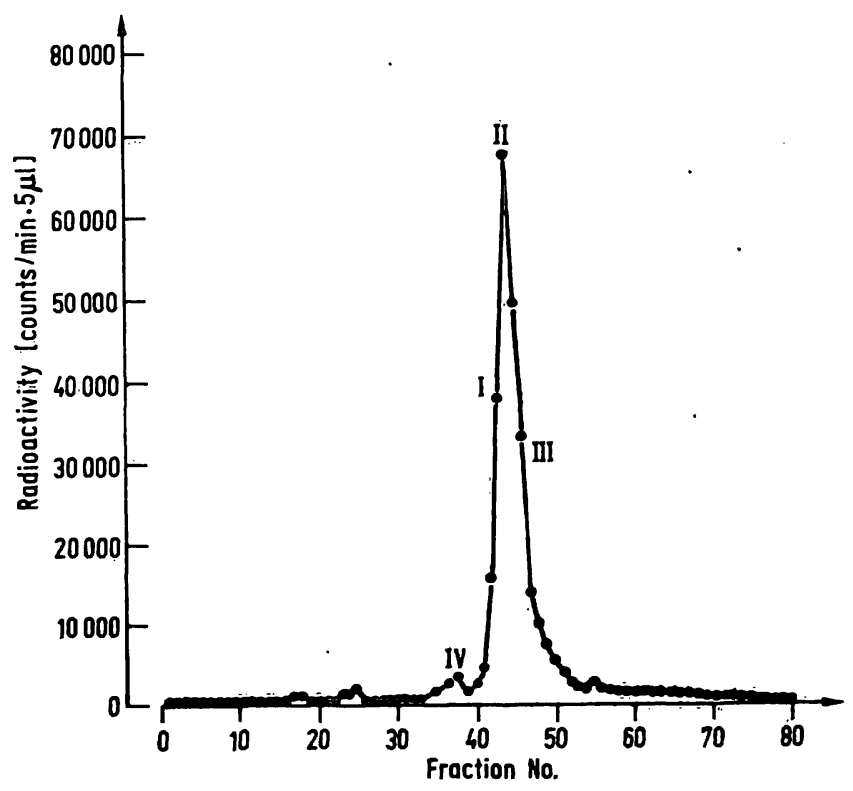

Fig. 2. Elution profile of ${ }^{125}$ I-human calcitonin on Ultrogel AcA 54 after Sephadex G-10 desalting. The maximum binding to the antibody is shown (incubation time $6 \mathrm{~h}$. Antibody dilution 1:1000). The elution profile on Ultrogel AcA 34 is identical - showing a single peak of immunoreactivity. Binding characteristics
' $\mathrm{B}_{0} \mathrm{~N}$
$\begin{array}{lll}\text { I } & 0.83 & 0.02\end{array}$
II $0.78 \quad 0.02$
III $0.70 \quad 0.02$
IV $0.90 \quad 0.24$ 
Tab. 2. Precision data - recovery, inter- and intra-assay coefficients of variation.

\section{a) Recovery}

In the range $0.15-10 \mu \mathrm{l} \cdot$ liter $^{-1}$. The recovery of added human calcitonin lay within the limits $(\overline{\bar{x}} \pm S D) 99.8 \pm 13.3 \%$ $(n=20)$.

\section{b) Precision}

1) Intra-Assay Coefficient of Variation (CV)

\begin{tabular}{|c|c|c|c|}
\hline & $\begin{array}{l}\bar{x} \\
8.72 \mu \mathrm{g} \cdot \text { liter }^{-1}\end{array}$ & SD & CV \\
\hline & $0.81 \mu \mathrm{g} \cdot$ liter $^{-1}$ & 0.07 & $\begin{array}{r}12.3 \% \\
9.43 \%\end{array}$ \\
\hline
\end{tabular}

2) Inter-Assay CV

\section{$\overline{\mathbf{x}}$}

Control 1

Control 2

Control 3

\section{$0.14 \mu \mathrm{g} \cdot \operatorname{liter}^{-1}$} $5.18 \mu \mathrm{g} \cdot$ liter $^{-1}$ $9.66 \mu \mathrm{g} \cdot$ liter $^{-1}$

\section{SD}

0.02

0.63

1.58

\section{CV}

$16.5 \%$

$12.3 \%$

$16.3 \% \quad 15$ dex G-10. It can be seen that no further purification than Sephadex G-10 is required as over $95 \%$ immunoreactivity is distributed over a single peak. The small forepeak (peak IV) has little or no effect on the assay system.

\section{Preparation of "human calcitonin free serum"}

Table 3 shows several serum components before and after extraction ( $100 \mathrm{~g}$ Florisil per liter serum). Figure 3 shows the radioactivity bound before and after Florisil in 7 sera and table 3 the electrophoretic pattern and concentration of several serum components before and after treatment. Figures $4 a-4 d$ show the effect of varying one component of the extraction system. The basic extraction system consisted of Florisil $200 \mathrm{~g} \cdot$ liter $^{-1}$ and an extraction time of $30 \mathrm{~min}$ at room temperature under constant shaking. The variable parameter is shown in the $\mathrm{x}$-axis of figures $4 \mathrm{a}-$ 4d. The tracer purity (tracer 10 weeks old) was estimated to be between $50 \%$ and $60 \%$ using column chromatography (estimated purity 52\%) and excess antibody binding (estimated purity $58 \%$ ). All extraction procedures

Tab. 3. Effect of Florisil extraction on certain serum components (sample K-7), extraction time $30 \mathrm{~min}$.

\begin{tabular}{lll}
\hline Component & Before treatment & After treatment \\
Total pịotein & $66 \mathrm{~g} \cdot$ liter $^{-1}$ & $62 \mathrm{~g} \cdot$ litèr $^{-1}$ \\
Albumin & 0.659 & 0.672 \\
$\alpha_{1}$-globulins & 0.030 & 0.029 \\
$\alpha_{2}$-globulins & 0.066 & 0.059 \\
$\beta$-globulins & 0.084 & 0.080 \\
$\gamma=$ globulins & 0.159 & 0.157 \\
& & \\
Creatinine & $80 \mu \mathrm{mol}^{-1} \cdot$ liter $^{-1}$ & $53 \mu \mathrm{mol}^{-1} \cdot$ liter $^{-1}$ \\
Uric Acid & 276 & 270 \\
Total Bilirubin & 5.44 & 2.21 \\
Cholesterol & 4530 & 4280 \\
Sodium & & \\
Potassium & $168 \mathrm{mmol} \cdot$ liter $^{-1}$ & $183 \mathrm{mmol} \cdot$ liter $^{-1}$ \\
Calcium & 15.4 & 8.4 \\
\hline
\end{tabular}

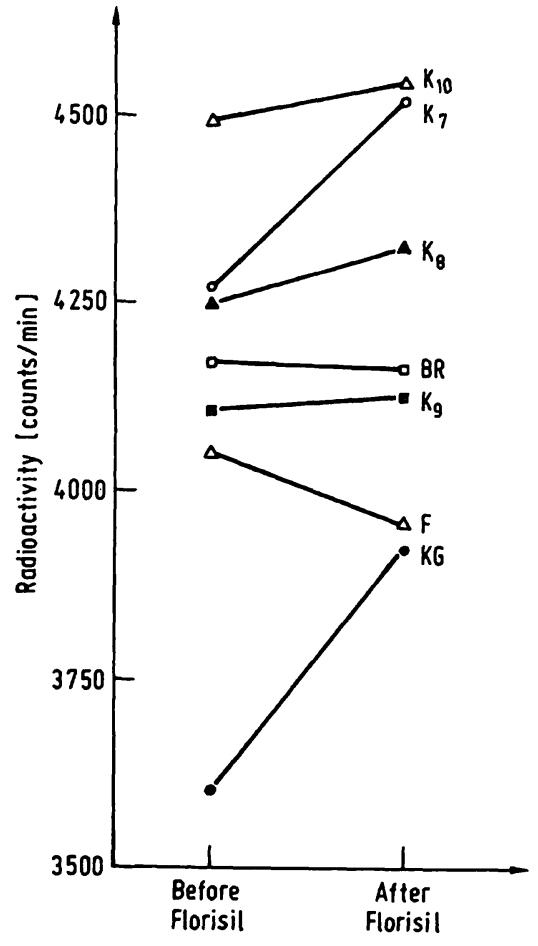

Fig. 3. Effect of Florisil ${ }^{\circledR}$ on immunoreactive human calcitonin in several serum and plasma samples. B.R., F., K. G. are patient sera and $K_{7}-K_{1}$ outdated blood plasma samples.

showed that Florisil extracted immunoreactive human calcitonin to within the expected limits. The system chosen for the extraction of the sera shown in figure 3 was that given above.

\section{Assay Conditions}

\section{Assay Standard Curves}

Figure 5 shows a typical standard curve for the human calcitonin assay. The effect of changing the amount of serum in one experiment had the following effect on the $50 \%$ intercept:

With $50 \mu \mathrm{l}$ serum the $50 \%$ intercept was $2.86 \mu \mathrm{g} \cdot$ liter $^{-1}$, with $100 \mu \mathrm{l}$ serum, $1.55 \mu \mathrm{g} \cdot$ liter $^{-1}$, and with $200 \mu \mathrm{l}$ serum, $1.09 \mu \mathrm{g} \cdot \operatorname{liter}^{-1}$. The $50 \mu \mathrm{l}$ assay showed a pronounced "hook-effect" which was not present with larger serum amounts.

In the earlier studies, $15 \%$ polyethyleneglycol was used as precipitant as also described elsewhere for parathyrin (9). Owing to unspecific effects with sera from patients with disproteinaemia - mainly dialysis patients, or those with Waldenström's disease - this method was changed to a double-antibody procedure, especially when the latter could be performed rapidly (5).

\section{Parallelism Studies}

Figure 6 shows the effect of diluting two sera from patients with medullary-thyroid carcinoma, serum $A$ from a dialysis patient and serum $B$ from a patient with normal 

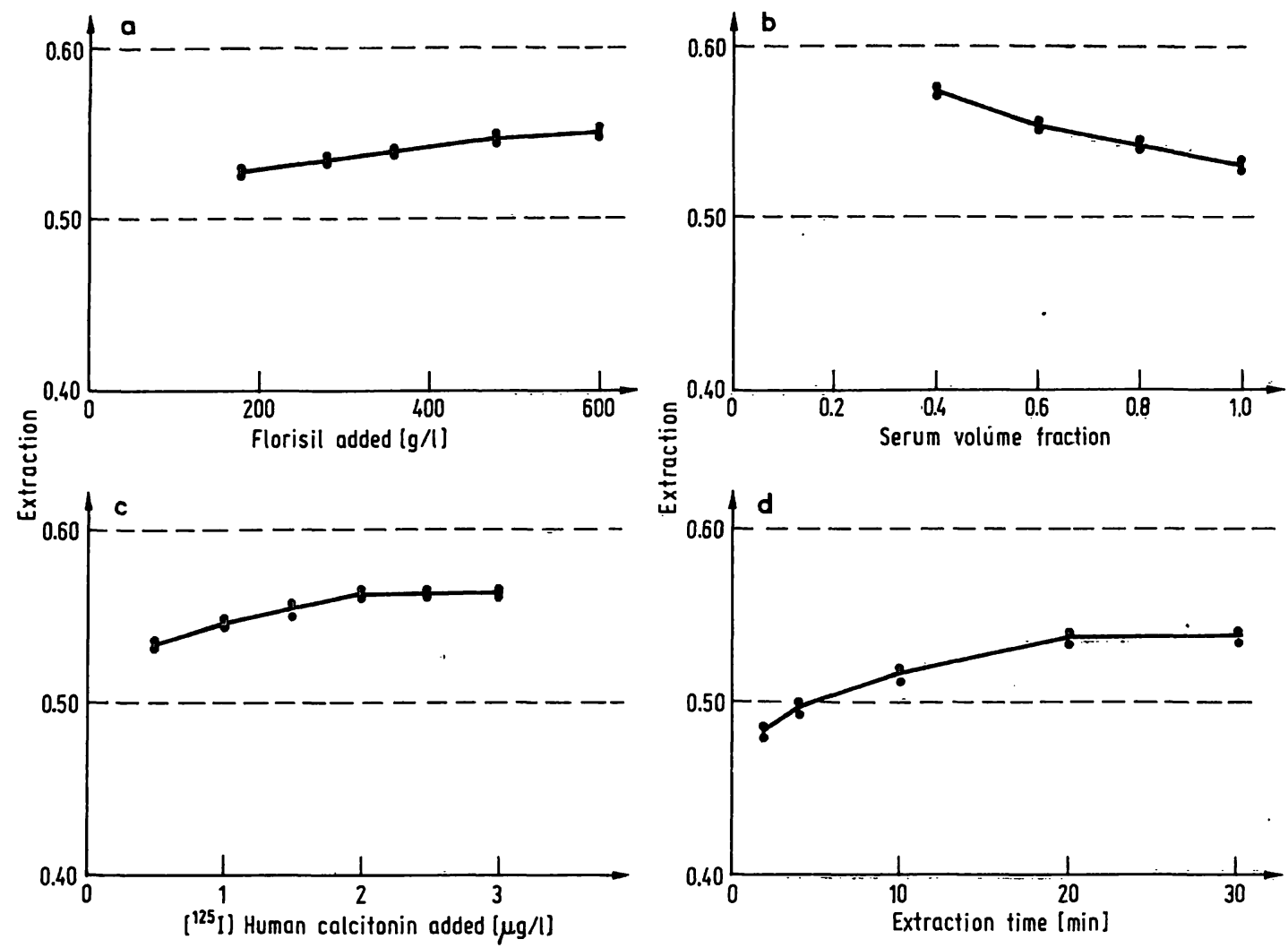

Figs. $4 \mathrm{a}-4 \mathrm{~d}$. Extraction of ${ }^{125}$ I-human calcitonin from serum. The expected extraction is $0.50-0.60$ (between the dotted lines) (Tracer purity - estimated at $0.52-0.58$ ). Figure $4 \mathrm{a}$ shows effect of varying the Florisil concentration, Figure $4 \mathrm{~b}$ shows the effect of varying serum, Figure $4 \mathrm{c}$ shows the effect of varying the amounts of ${ }^{125}$ I-human calcitonin and Figure $4 \mathrm{~d}$ the effect of varying the extraction time.

The "standard system" consisted of Florisil $200 \mathrm{~g} \cdot \operatorname{liter}^{-1}$ serum, $1 \mu \mathrm{g} \cdot \operatorname{liter}^{-1}$ human calcitonin, extraction time 30 min at room temperature.

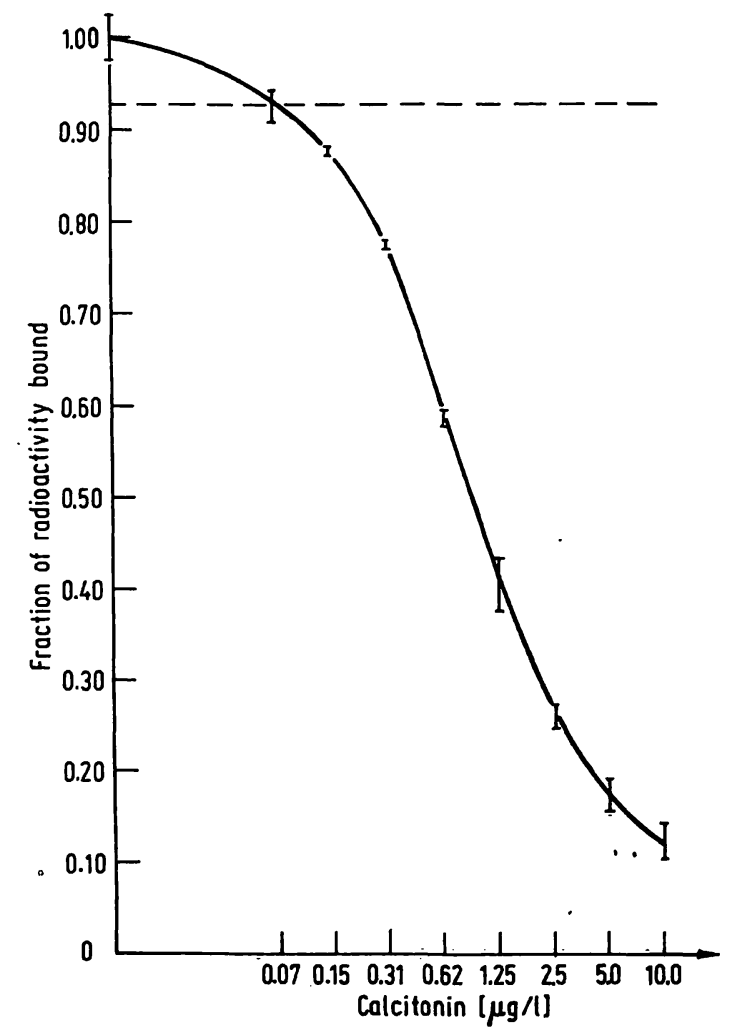

Fig. 5. Typical standard curve for human calcitonin-radioimmunoassay. 0.50 intercept $0.88 \mu \mathrm{g} \cdot$ liter $^{-1}$. The dotted line shows the lower limit of detection $\left(0.08 \mu \mathrm{g} \cdot\right.$ liter $\left.^{-1}\right)$.

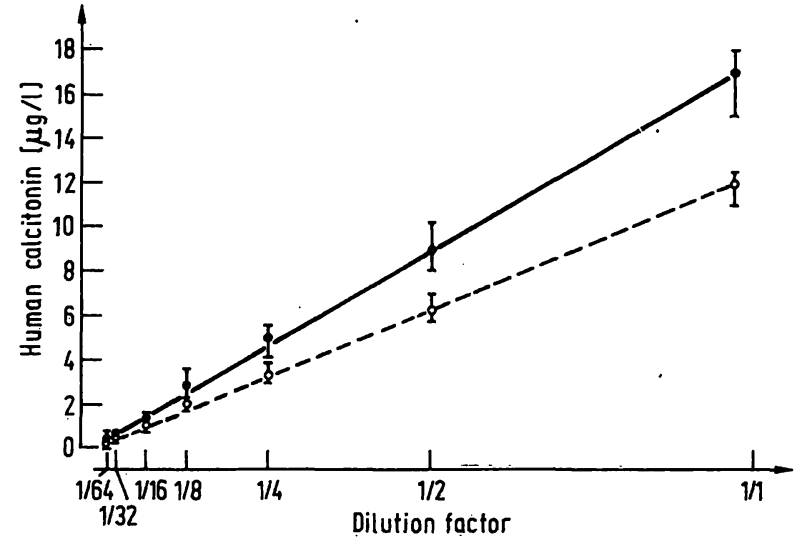

Fig. 6. Serial dilution of two serum samples.

Serum A - patient with medullary thyroid carcinoma and renal failure $(\bullet-\bullet)$

Serum B - patient with medullary thyroid carcinoma and normal renal function (•- - $\bullet$ ).

The results are the mean and standard dilution of triplicate measurements.

renal function, using the 2 . Ab separation technique. Both were diluted with human calcitonin-free serum and diluted out as expected. The results shown are mean and standard deviation of triple determinations. 


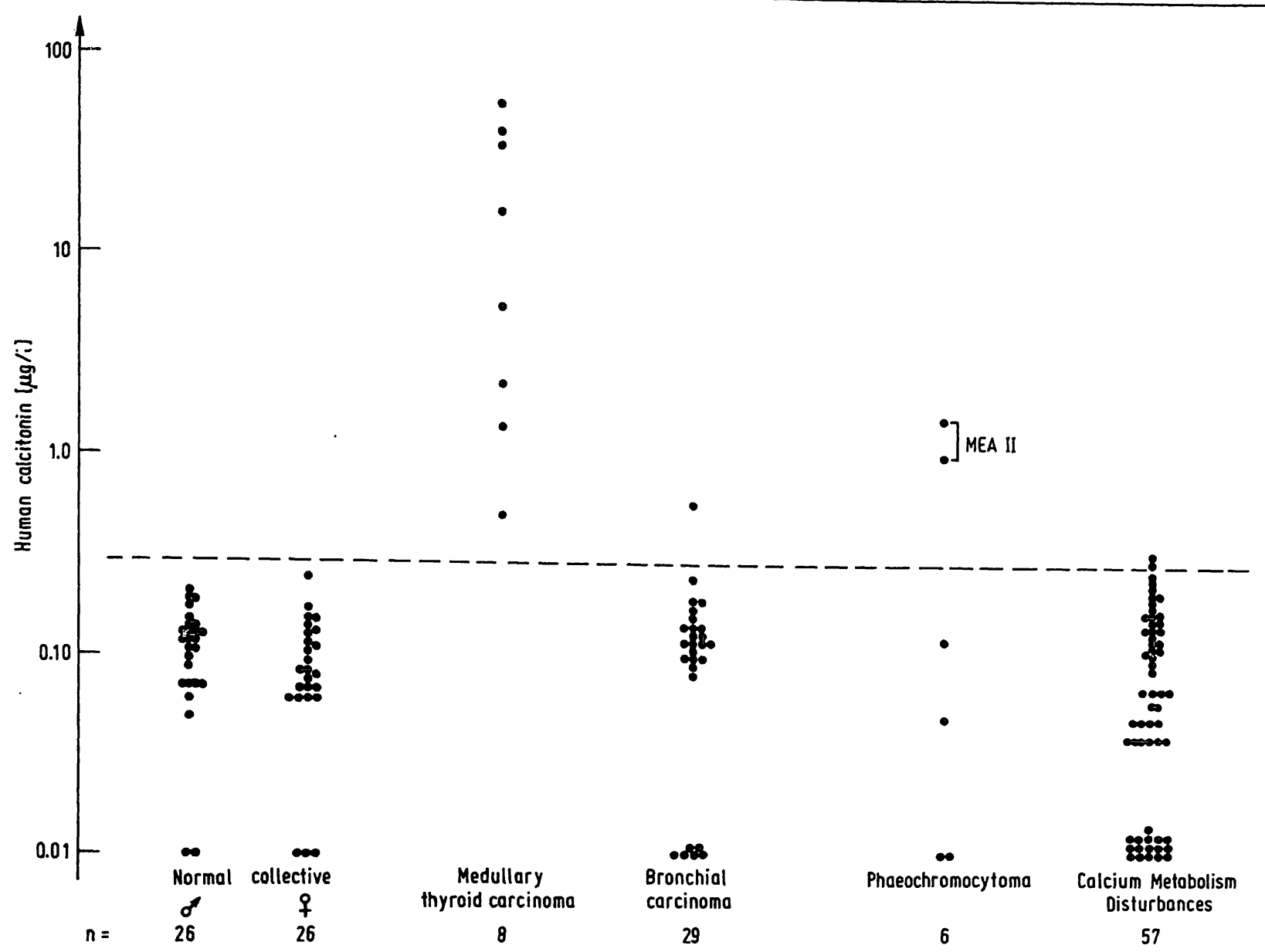

Fig. 7 a. Scattergram of the patient groups. Dotted line shows upper limit of normal range $\left(<0.05-0.30 \mu \mathrm{g} \cdot \mathrm{liter}^{-1}\right)$. Key: MEA II = multiple endocrine neoplasia type II.

\section{Intra- and Interassay Coefficients of Variation (CV)}

Table 2 shows the intra- and interassay $\mathrm{CV}$ over the whole range of the standard curve. The interassay $\mathrm{CV}$ was carried out over a 3 month-period.

\section{Clinical Studies}

Figure 7 a shows the immunoreactive human calcitoninlevels found in 52 normal patients compared with a group of 8 patients with medullary thyroid carcinoma, 29 patients with bronchial tumors, 5 phaeochromocytoma patients, and 57 patients with calcium metabolism disorders (renal stones, hyper- and hypoparathyrinaemia). Only the patients with medullary thyroid carcinoma and confirmed multiple endocrine adenoma III-cases showed significantly elevated human calcitonin levels.

The normal collective had a normal calcium metabolism, were aged 18-67 years and were distributed evenly between the sexes $(\delta, q=26)$. The difference in human calcitonin levels between the sexes in the normal collective was not statistically significant (p 0.2 (Wilcoxon Rank test)). Six patients with phaeochromocytoma were studied and their human calcitonin levels ranged from $0.04-1.28 \mu \mathrm{g} \cdot$ liter $^{-1}$. Figure $7 \mathrm{~b}$ shows patients with disturbed calcium metabolism, measured at the same time, including the patients with medullary thyroid carcinoma and 14 normal volunteers. Two dialysis patients showed slightly elevated values. Figure 8 shows the pre- and postoperative human calcitonin levels in a patient with lung metastases from a medullary thyroid carcinoma during cytostatic treatment. Clinical symptoms correlated well, but cytostatic treatment had to be discontinued due to severe side-effects in the haematopoietic system.

\section{Discussion}

Although the assay for human calcitonin in serum is very rarely an emergency one, the need for rapid and sensitive assays is present, especially in rationalisation of assay procedures; and also because of the theoretical consideration that the quicker the assay, the less the likelihood that degradation of the hormone may give rise to false results. The affinity constant of the antiserum used here 


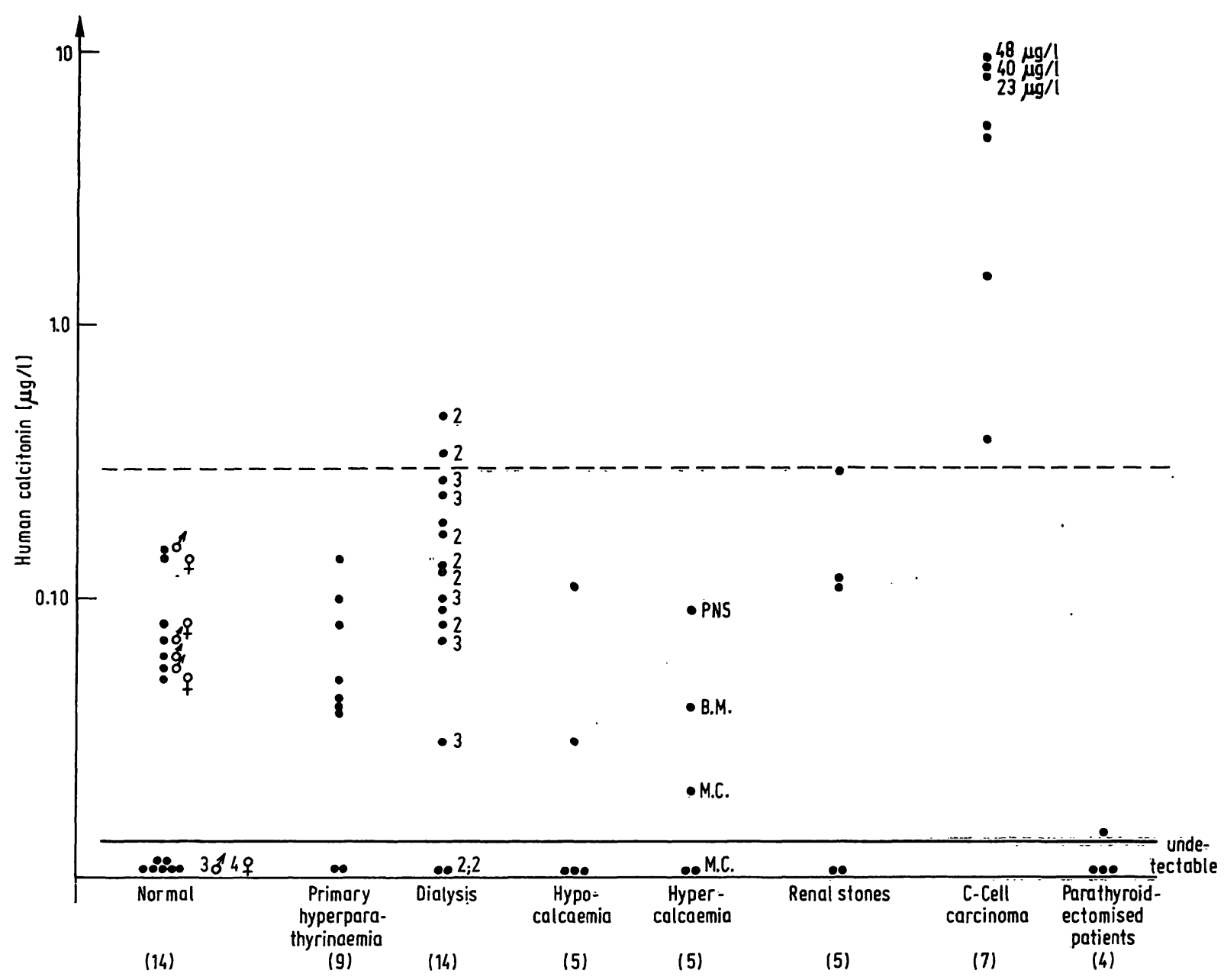

Fig. 7 b. Scattergram of normal volunteers and patients with selected calcium metabolism disorders (including patients with medullary thyroid carcinoma) measured in a single assay.

Key: 2 and 3 (Dialysis group) = secondary and tertiary hyperparathyrinaemia; Parathyroidectomised patients without reimplantation. Dotted line shows upper limit of normal range $\left(<0.05-0.30 \mu \mathrm{g} \cdot \operatorname{liter}^{-1}\right)$

M.C. = Mammary carcinoma

PNS = Paraneoplastic syndrome

B.M. = Bone metastases

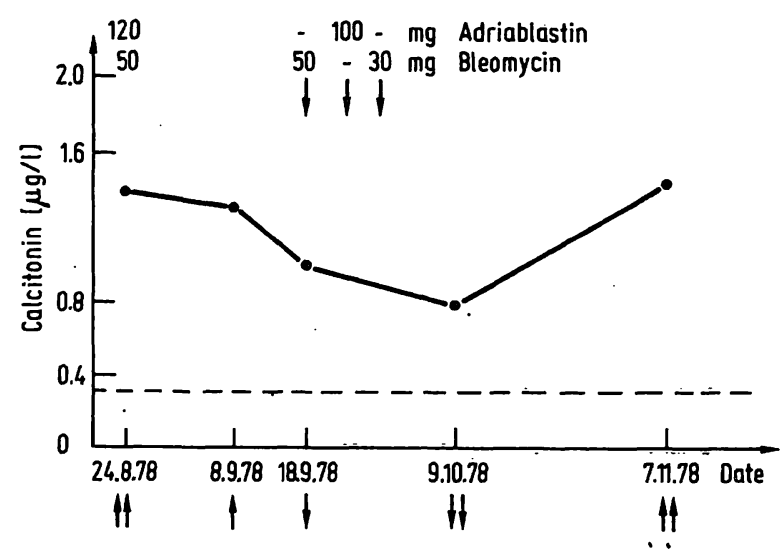

Fig. 8. Patient T.S. (\$ 72a). Control of serum calcitonin levels under chemotherapy for medullary thyroid carcinoma with lung metastases.

Dotted line shows upper limit of normal range $(<0.05-$ $0.30 \mu \mathrm{g} \cdot \mathrm{liter}^{-1}$ ).

Serum calcium $2.4 \mathrm{mmol} \cdot$ litere $^{-1}$, serum phosphorus $0.9 \mathrm{mmol}^{-}$liter -1

$\uparrow, \downarrow$ Incidence of lung metastases (Xray scans) makes it possible to run such quick assays without loss of sensitivity. The addition of aprotinin to the buffer system was to prevent protease activity - or at least hinder it. Non equilibrium assay conditions have been shown to be more sensitive than equilibrium ones (10), and this, coupled with pre-incubation, improves the sensitivity/assay time relationship.

The use of non-specific precipitation methods was tried out at first using polyethyleneglycol, but due to the unspecific effects in disproteinaemic sera (11), this was only used until a double-antibody technique was perfected. The disadvantage of adding doüble-antibody alone was the slow kinetics (5) but with addition of polyethyleneglycol to a final concentration of $30-50 \mathrm{~g}$. liter ${ }^{-1}$ this reaction was speeded up by over 1000 -fold (5), so that the method was as quick as polyethyleneglycol and quicker than charcoal (2) without the time dependency of the latter. The quality-control of the assay is satisfactory as seen in table 2 . 
The capacity of the assay to measure human calcitonin accurately is seen in the assay of sequentially diluted sera where the expected value lay very near to the measured value. The acquisition of human calcitonin-free serum by extraction with Florisil, although not all sera are useable.

It has been observed that when sera are not frozen at under $-20^{\circ} \mathrm{C}$ within $24 \mathrm{~h}$ of receipt that a loss of immunoreactivity is seen, i.e. the binding in the assay falls off, giving rise to falsely elevated results. Treatment with Florisil does not restore the immunoreactivity. Samples F and BR in figure 3 show this effect, and it must be put forward that this is not due to a change in human calcitonin (which would have to be generated!) but to degradation of component(s), perhaps in the complement system, which enhance the antigen-antibody reaction.

The use of the human calcitonin assay in clinical diagnosis has been intensively investigated and also reports have been given where serum human calcitonin levels are raised in patients with various tumors $(3,12)$ other than medullary thyroid carcinoma. In this laboratory, consistenly elevated-levels have only been found in patients with medullary thyroid carcinoma.

In two patients, mother and daughter, with phaeochromocytoma removed 6 months and 12 years before, but without confirmed medullary thyroid carcinoma elevated human calcitonin was found which agree with the symptoms of multiple endocrine neoplasia type II (13). The value of human calcitonin as a general tumor marker is doubtful in the light of the present study. In the patients with bronchial carcinoma, serum corticotropin levels were also normal (Müller, O. A., unpublished results) in contrast to other studies $(14,15)$. One reason for this discrepancy may very well be due to the specificity of the antisera used, i.e. whether it is $\mathrm{C}$ - or N-regional specific (15), and future studies must be carried out to determine the specificity of the antiserum to different regions of human calcitonin.

The use of the human calcitonin-assay using this antisera seems to be limited to the detection and followup of medullary thyroid carcinoma, and multiple endocrine adenoma type II in which production of human calcitonin can occur both in the adrenal medulla and the $\mathrm{C}$-cells of the thyroid as both have a common embryological source.

\section{Acknowledgements}

The authors wish to thank Fräulein Christine Wachter for technical assistence, Fräulein Fides Haag for photography, Frau Irma Wiktorin for the artwork, and Frau Marianne Preisendanz for typing the manuscript.

\section{References}

1. Tashjian, A. H. jr., Howland, B. G., Malvin, K. E. W. \& Hill, C. S. jr. (1970), N. Engl. J. Med. 283, 890-895.

2. Deftos, L. J. (1971), Metabolism 20, 1122-1128.

3. Hillyard, C. J., Coombes, R. C., Greenberg, P. B., Galante, L. S. \& MacIntyre I. (1976), Clin. Endocrinol. 5, 1-8.

4. Tashijian, A. H. jr., Wolfe, H. J. \& Voelkel, E. F. (1974), Amer. J. Med. 56, 840-849.

5. Wood, W. G., Stalla, G., Müller, O. A. \& Scriba, P. C. (1979), J. Clin. Chem. Clin. Biochem. 17, 111-114.

6. Raue, F., Minne, H., Streibl, W. \& Ziegler, R. (1978), Calcitonin radioimmunoassay: Clinical application. In: Radioimmunoassay and Related Procedures in Medicine. 1977. IAEA, Vienna, p. 419-426.

7. Wood, W. G., Marschner, I. (1978), Acta Endocrinol. (Kbh.) Suppl. 215, 113-116.

8. Erhardt, F., Marschner, I., Pickardt, C. R. \& Scriba, P. C. (1973), J. Clin. Chem. Clin. Biochem. 11, 381-387.
9. Wood, W. G., Kuflicki, G., Marschner, I. \& Scriba, P. C. (1978), Acta Endocrinol. (Kbh.) Suppl. 215, 116-117.

10. Wide, L., Willins, S. J., Gemzell, C. \& Ross, P. (1973), Acta Endocrinol. (Kbh.) 72 Suppl. 174, 73.

11. Wood, W. G., Marschner, I. \& Scriba, P. C. (1979), Horm. Metab. Res. 11, 309-317.

12. Silva, O. L., Becker, K. L., Primack, A., Doppmann, J. L. \& Snider, R. H. (1976), Chest 69, 495-499.

13. Wells, S. A., Ontjes, B. A., Cooper, C. W., Henessy, J. F., Ellis, G. J., MacPherson, H. T. \& Salaston, D. C. (1975), Ann. Surg. 182, 362-370.

14. Grewitz, G. \& Yalow, R. S. (1974), J. Clin. Invest. 53, $1022-1032$.

15. Odell, W. D. (1978), We don't look at hormones the way we used to. In: Radioimmunoassay and Related Procedures in Medicine, 1977. IAEA, Vienna, pp. 3-41.

Dr. William Graham Wood,

Laboratorien für Klinische Chemie und Endokrinologie, Medizinische Klinik Innenstadt der Universität München, Ziemssenstraße 1,

D-8000 Munich 2

Federal Republic of Germany. 


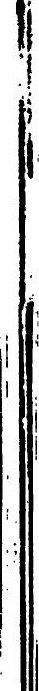




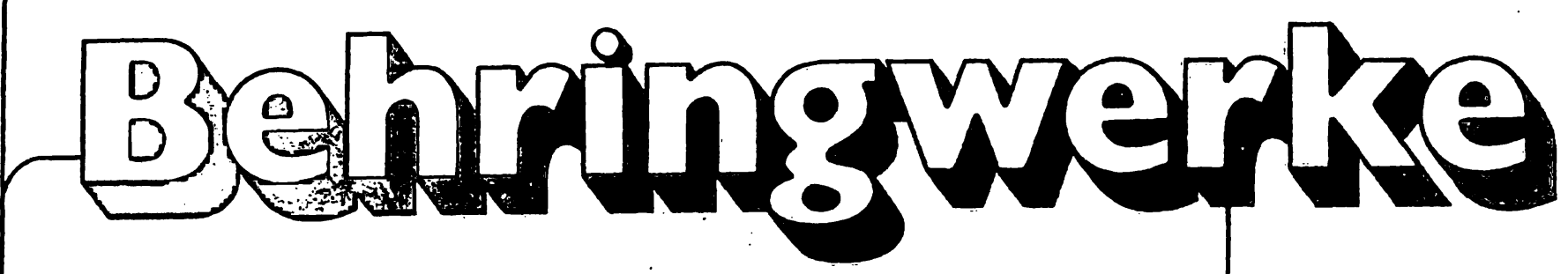

Wir sind ein namhaftes Unternehmen der pharmazeutischen Industrie mit Sitz̧ in der Universitätsstadt Marburg und gehören zur Hoechst-Gruppe.

Im Namen unserer virologischen Forschung entwickeln wir neue Präparate für Therapie und Prophylaxe und suchen deshalb einen jüngeren

\section{Naturwissenschaftler/}

\section{(Virologen, Biochemiker, Mikrobiologen oder Tierarzt)}

der über ein entsprechendes Thema promoviert hat, auf einem verwandten Gebiet tätig ist oder Erfahrungen und Interesse an virologischen Aufgaben in der. pharmazeutischen Forschung hat. Sie sollten nicht über 30 Jahre alt sein, gute Englischkenntnisse besitzen und zur Teamarbeit in der Lage sein.

Unsere finanziellen und sozialen Leistungen sowie die näheren Einzelheiten dieser Position, möchten wir in einem persönlichen Gespräch erörtern.

Bitte richten Sie Ihre Bewerbung zunächst mit ausführlichen Unterlagen an die

Personalabteilung der

Behringwerke AG, Postfach 1140, 3550 Marburg/Lahn 1

G. Kahl (Editor)

Biochemistry

of Wounded Plant Tissues

Edited by Dr. Günter Kahl, Professor for Botany, Department of Biology, Johann Wolfgang Goethe University of Frankfurt am Main.

1978. $17 \mathrm{~cm} \times 24 \mathrm{~cm} .684$ pages. Hardcover DM 180.00 ISBN $311006801 X$

This volume comprises original studies and survey articles by competent scientists from world-famous laboratories. It offers an overview of the present state of knowledge as regards the biochemistry and molecular biology of wound processes and woundhealing mechanisms as based on model systems from the plant kingdom. Extensive bibliographies of most recent literature are appended to each article, making the volume a rich source of information. 